\title{
Reflective Thinking AND Probabilistic Thinking: AN EXAMPLE OF ELEMENTARY SCHOOL STUDENTS
}

\author{
Feride OZYILDIRIM-GUMUS, GuInar OZYILDIRIM
}

\begin{abstract}
Reflective thinking, problem solving and probabilistic thinking are important processes in mathematics education and considered to what extent those processes can be carried out by elementary school students is essential. The study is conducted with 188 eighth grade students. As a result, no significant difference is observed in reflective thinking towards problem solving and probabilistic thinking scores according to gender. Also, no significant relationship is found between reflective thinking and probabilistic thinking. However, based on gender, random similarity dimension of probabilistic thinking test shows a low relationship with questioning dimension of Reflective Thinking Skill Scale Towards Problem Solving in terms of females.
\end{abstract}

Key words: probability, teaching probability, learning probability, problem solving, thinking reflectively, probabilistic thinking

\section{Introduction}

The process of thinking, especially reflective thinking, which is understood to be important in both teacher and student learning, is defined as a standard and from past to present and many commissions, institutions, countries and local school administrations have thought that all students and teachers should endeavor on this (Rodgers 2002). The reflection process helps learners to gain new knowledge while reducing imbalances of them (Xie, Ke, and Sharma 2008). Reflective thinkers are aware of their learning, in this way, they can control their learning, recognize what they have learned and what they need to learn. Besides, they know how to complete the gaps between their learning (Dewey, 1933). Thus, the student will be able to evaluate their own learning from a critical point of view; to make sense of himself / herself and the information better and to increase his / her learning at maximum level (Xie, Ke, and Sharma 2008).

\section{1. Reflective Thinking and Problem Solving}

In literature reflective thinking is defined as "active, persistent, and careful consideration of any belief or supposed form of knowledge in the light of the grounds that support it and the further conclusions to which it tends" (p. 7) by Dewey (1933). The other definition is given by Baron (1981), as thinking of options and reasons before adopting a belief or selection of options related to an action. Moreover, Schön (1987) discusses reflective thinking through two concepts as reflection-on-action and reflection-in-action. The reflection-in-action is explained as focusing on solving the situation at the time of an action, and reflection-on-action is clarified as evaluation of action after the action is completed by the researcher. Besides, Lee (2005) states that reflective thinking consists of three stages: recall; which means that a person is able to imitate his/her learning by defining his/her past experiences, interpretation; which is that he/she is able to find new ways by analyzing his/her experiences and reflection; which he/she is able to carry out future evaluation and to observe its effect.

Rodgers (2002, p. 845) agrees with the definition of Dewey (1933) on reflective thinking, however; the researcher pointed four elements in order to gain functionality to it.

- Reflection is a meaning-making process that moves a learner from one experience into the next with deeper understanding of its relationships with and connections to other experiences and ideas. It is the

Cite as: Ozyildirim-Gumus, F. \& Ozyildirim, G. (2020). Reflective Thinking and Probabilistic Thinking: An Example of Elementary School Students. Acta Didactica Napocensia, 13(1), 43-56, https://doi.org/10.24193/adn.13.1.5 
thread that makes continuity of learning possible, and ensures the progress of the individual and, ultimately, society. It is a means to essentially moral ends.

- Reflection is a systematic, rigorous, disciplined way of thinking, with its roots in scientific inquiry.

- Reflection needs to happen in community, in interaction with others.

- Reflection requires attitudes that value the personal and intellectual growth of oneself and others.

When it comes to the stages of reflective thinking, Dewey (1933) points out that there are five stages describing nonrigid real steps for reflective thinking, which are presented below.

- The first solution or action suggestion which isn't carried out because it is doubted;

- Intellectualisation of an issue whose difficulty should be solved, called that designing of a problem statement;

- Usage of a proposition as a hypothesis which guides forward thinking;

- The preparation of a thought or an assumption by mental processes that is, reasoning in narrower sense;

- Testing hypotheses with actions and thoughts.

If those steps are examined more closely, the relation between them and problem-solving steps of Polya (1945) is clearly seen. Polya, arrays the problem-solving steps as understanding problem, devise a plan, carrying out the plan and looking back as evaluation. According to the problem-solving steps of Polya (1945), in the understanding problem process, a person tries to understand the problem and to examines the information given primarily. In this step, the person expresses his / her thoughts and use different notations. It can be stated that this step resembles the first two stages of Dewey's (1933) reflective thinking steps, which are the first solution or action suggestion that is not carried out and intellectualisation of an issue whose difficulty should be solved, called that designing of a problem statement. Baron (1981) mentions that the first step of problem-solving process as recognizing of a problem, which supports this view. Following this step, it can be interpreted that the second and third problem solving steps of Polya which are devise a plan and carrying out it, remind the third and fourth reflective thinking stages of Dewey (1933) which is usage of a proposition as a hypothesis which guides forward thinking and the preparation of a thought or an assumption by mental processes that is, reasoning in narrower sense. Finally, it is concluded that the fourth step, looking back, of Polya serves at same purpose with testing hypotheses with actions and thoughts which fifth reflective thinking stage of Dewey. That's why it is concluded that the reflective thinking process and the problem-solving process may be in a relationship.

\subsection{Probability and Probabilistic Thinking in Mathematics Education}

The probability learning area is placed in the mathematics curriculum of our country, starting from eighth grade at elementary school. Formally, students encounter the concept of probability in the eighth grade, although in fact, they use this concept knowingly or unknowingly from a younger age. The concepts related to probability are generally used in the decision-making process of an uncertain situation in our daily lives. This process, which is so intertwined with daily life, makes probabilistic thinking important. In order to improve probabilistic thinking, it is thought that encountering the students with daily life problems can have a positive effect. In this way, Bezzina (2004) states that students can find logical solutions that are different from known rules or methods. In addition, it will be possible to understand the mathematical knowledge and to establish the relations between those knowledges during problem solving (Swings and Peterson 1988), in this process, a mental process, mathematical thinking and reasoning also comes into play. Related literature also supports that idea. For instance, Fong, Krantz and Nisbett (1986) and Kosonen (1992) report that receiving education related to everyday life problems about probability improved reasoning ability. On the other hand, some studies have shown that students experience difficulties in probabilistic thinking and reasoning (Shaughnessy, 1992; Kafoussi, 2004). For this reason, it may be thought that it is important and necessary to know the variables that may have an effect on probabilistic thinking in order to overcome those difficulties and to construct the curriculum according to those variables. 


\subsection{Aim of the Study}

When the literature about probabilistic success and the variables which are effective on probabilistic thinking is examined, there are researches related to the variables such as culture, language and religion (Amir \& Williams, 1999), age (Watson \& Moritz, 2002; Way, 2003) and gender (Lamprianou \& Lamprianou, 2003). Moreover, reflective thinking is defined as an important ability to be investigated, measured and evaluated (Kızılkaya \& Aşkar, 2009). In addition, Chen, Seng, Moo, Tan, and Steven (1992) states that problem solving and reflective thinking is interrelated. When the variables which may have an effect on probabilistic thinking are examined in the literature, there is no study investigating a relationship related to reflective thinking used in problem solving. Therefore, in this study, the relationship between reflective thinking towards problem solving and probabilistic thinking is examined. The number of the studies conduct with students at elementary and high schools about reflective thinking is limited (Baş, 2013; Baş \& Beyhan, 2012; Baş \& Kıv1lcım, 2012; Ersözlü, 2008; Kızılkaya, 2009; Kızılkaya \& Aşkar, 2009). Besides, since the students are formally encountered the probability learning area in the eighth grade for the first time and majority of the research on this topic is carried out with teachers and pre-service teachers (Erginel, 2006; Köksal \& Demirel, 2008; Şahin, 2009; Şanal, 2006; Yorulmaz, 2006), eighth grade students are chosen as sample within the scope of the study is that. In one of those studies, the relationship between high school students' mathematics as well as geometry course and reflective thinking skills are examined (Baş \& Kıvılcım, 2012). However, as there is no study investigating the relationship between probabilistic thinking and reflective thinking in problem solving. So, the research problems in this study are determined as follows:

- Do the reflective thinking skills towards problem solving of elementary school students differ according to gender?

- Do the probabilistic thinking test scores of the elementary school students differ according to gender?

- Is there a relationship between the reflective thinking skills towards problem solving of elementary school students and their probabilistic thinking scores?

\section{Method}

\subsection{Research Model}

This study is designed with relational screening model which is one of the quantitative research methods. In relational research, whether there is any possible relationship between two or more variables is investigated. Unlike experimental research, variables are not interfered in relational studies (Fraenkel \& Wallen, 2009). "Correlational analysis is done through two ways: These are correlation type relationship and relationship which is obtained via comparison... In the research related to correlation type relationship, whether or not the variables change together, if there is a change, it is tried to learn how this change has occurred." (Karasar 2011, pp. 81-82). In this study owing to the fact that the relationship between the two variables are examined, correlation type of relational screening model from quantitative research methods is selected.

\subsection{Population and Sample}

The population of the research included students who are studying in the eighth grade at elementary schools in a medium-sized province of country located in central regions in spring semester of 20172018 academic year. 210 eighth-grade students are reached from three public schools through stratified sampling. Stratified sampling, one of the random sampling methods, is the process of grouping of the population into subgroups or strata (Fraenkel and Wallen 2009). Since some students have filled out their data collection tools deficiently or wrongly; therefore 22 students' data are omitted to the research and the analysis process is conducted with data collected from 188 students. The sample consists of 98 male students (52\%) and 90 female students (48\%). 


\subsection{Data Collection Tools}

Reflective Thinking Ability Scale towards Problem Solving (Kızılkaya \& Aşkar, 2009) is used in order to assess the reflective thinking skills of the students during problem solving process and a multiple-choice test developed by Afantiti-Lamprianou and Williams (2003) which includes 13 probability problems is used to determine the probabilistic thinking scores are used in the scope of the research. Detailed information related to these instruments are presented as below.

2.3.1. Reflective Thinking Ability Scale towards Problem Solving. Reflective Thinking Ability Scale Towards Problem Solving, developed by Kızılkaya and Aşkar (2009), is used to determine the reflective thinking skills of the students. The scale includes fourteen items and three dimensions which are reasoning, questioning and evaluation. It is a five-point likert scale. The reliability values are reported to be at the appropriate level for dimensions and total score during the development of the scale which is conducted with seventh grade students by Kızılkaya and Aşkar (2009). Since this study is conducted with eighth grade students, confirmatory factor analysis is performed with data from eighth grade students. The related analysis results are presented in Table 1.

Table 1. Confirmatory Factor Analysis Results of Reflective Thinking Ability Scale towards Problem Solving

\begin{tabular}{|l|l|l|l|l|l|l|l|l|l|l|}
\hline Models & $\boldsymbol{\chi} \mathbf{2}$ & $\mathbf{d f}$ & $\boldsymbol{\chi 2} / \mathbf{s d}$ & $\mathbf{p}$ & NFI & NNFI & AGFI & GFI & CFI & RMSEA \\
\hline Model 1 & 138.42 & 74 & 1.870 & 0.00 & 0.92 & 0.95 & 0.82 & 0.87 & 0.96 & 0.083 \\
\hline Model 2 & 126.00 & 73 & 1.726 & 0.001 & 0.93 & 0.96 & 0.84 & 0.89 & 0.97 & 0.072 \\
\hline Model 3 & 114.77 & 72 & 1.594 & 0.001 & 0.93 & 0.97 & 0.85 & 0.89 & 0.97 & 0.065 \\
\hline
\end{tabular}

As seen Table 1, values of AGFI (= .82); GFI $(=.87)$ and RMSEA $(=.08)$ are not suitable in Model 1. Therefore, an error covariance is applied between item 9 and item 13 and Model 2 is obtained. In Model 2, it is seen that the AGFI $(=.84)$ value is still low and second error covariance is applied between item 8 and item 11 as well as Model 3 is obtained. The structure related to Model 3 is presented in Figure 1. The values of conformity factor analysis are $\chi 2=114.77, \mathrm{df}=72, \mathrm{p}=.00$, RMSEA $=.065, \mathrm{CFI}=.97, \mathrm{NFI}=.93, \mathrm{NNFI}=.97$ and $\mathrm{GFI}=.89$. Thus, all values in Model 3 are appropriate for goodness of fit indexes (Anderson \& Gerbing, 1984; Cole 1987). The diagram for the relevant model is presented in Figure 1. 


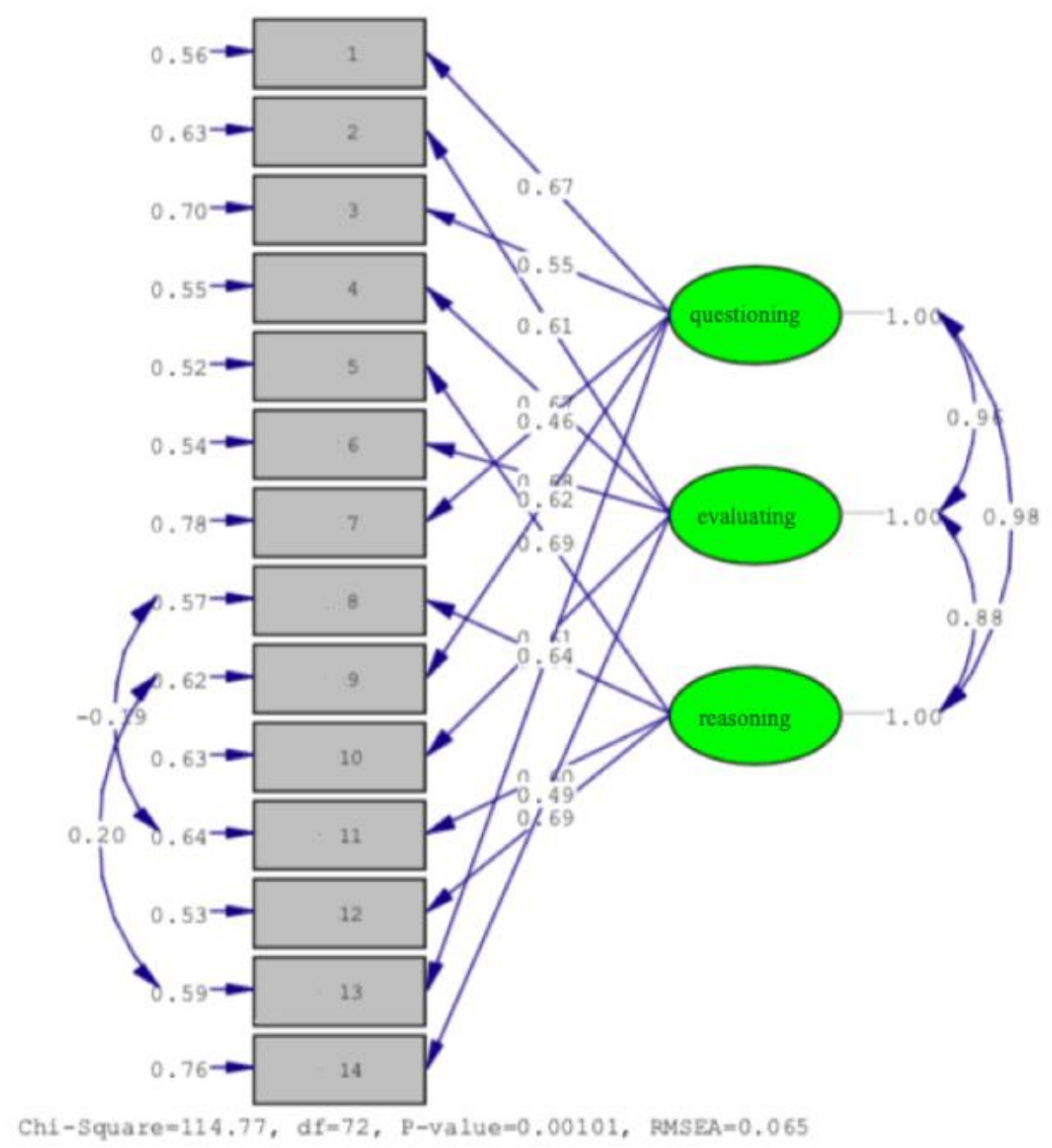

Figure 1. Confirmatory Factor Analysis Structure of Reflective Thinking Ability Scale towards Problem Solving

As seen in Figure 1, questioning dimension includes items 1-3-7-9 and 13; evaluation dimension includes items 2-4-6-10 and 14; and lastly reasoning dimension includes items 5-8-11 and 12, that all items are placed in like original form of the scale. In addition, according to the data obtained for this study, the Cronbach alpha value for whole scale is .89; for the questioning dimension, it is .73; for the reasoning dimension, it is .75 and for evaluation dimension, it is .73. According to these values, it can be said that the scale is reliable (Akgül \& Çevik, 2003).

2.3.2. Probabilistic Thinking Test. The multiple-choice test, consisting of thirteen items and developed by Afantiti-Lamprianou and Williams (2003), is used to determine their probabilistic success scores of students. The test is about children's intuitive thinking and reasoning processes related to probablity (Afantiti-Lamprianou and Williams 2003) and assesses their representativeness tendency related to the probabilistic thinking. It includes four dimensions, named as recency (items 12-3), the random-similarity (items 4-5-6-8), the base-rate frequency (items 10-11-12) and the sample size (items 7-9-13). Items 1-2 and 3 in original tool, are prepared to test the negative recency effect related to an outcome with a long sequence, followed by the other outcome to equilibrate the proportions. Items 4, 5, 6 and 8 are prepared to test random-similarity which means a sample look like the population and appear to be apparently random. Items 10-11 and 12 are prepared to test base-rate related to the effect of the previous ratios or base rates of results on the context and as a result with misleading, relevant, stereotyped information, the previous possibilities are ignored. Lastly items 7, 9 and 13 are prepared to test the tendency to neglect the sample size in estimation of probability. 
Since the test consisted of multiple-choice items, the data are coded by giving 1 point for each correct answer and 0 point for each wrong or blank answer. The test is translated into the necessary language and presented to experts in the field, for the culture and language appropriateness. Required revision is done within the framework of the feedback received from the experts and re-translated into English is done for back translation. It is concluded that retranslation of items is compatible with items of original scale. After that, this test is applied to 80 eighth grade students who had similar characteristic with the sample, for validity and reliability studies and item analysis is carried out. The results of item analysis are presented in Table 2.

Table 2. The results of item analysis of Probabilistic Thinking Test

\begin{tabular}{|l|l|l|l|}
\hline Item Number & Item Diff. & Disc. Index & Belonging factor \\
\hline Item 1 & .90 & .24 & recency \\
\hline Item 2 & .80 & .56 & recency \\
\hline Item 3 & .84 & .27 & recency \\
\hline Item 4 & .86 & .38 & random similarity \\
\hline Item 5 & .85 & .35 & random similarity \\
\hline Item 6 & .15 & .08 & random similarity \\
\hline Item 7 & .05 & .13 & sample size \\
\hline Item 8 & .20 & -.02 & random similarity \\
\hline Item 9 & .11 & .17 & sample size \\
\hline Item 10 & .80 & .44 & base rate \\
\hline Item 11 & .30 & .61 & base rate \\
\hline Item 12 & .26 & .52 & base rate \\
\hline Item 13 & .10 & -.16 & sample size \\
\hline
\end{tabular}

As seen in Table 2, items 6-7-8-9 and 13 have low discrimination indexes. Afantiti-Lamprianou and Williams (2003) also state that items 6-8 and 13 are problematic during validity and reliability studies. In addition, according to Ebel (1972) items with lower discrimination index than .19, are considered as poor items. For this reason, items 6-7-8-9 and 13 are removed from the test. Again, an item analysis is conducted with remaining 8 items and results are presented in Table 3.

Table 3. The results of item analysis of remaining 8 items of Probabilistic Thinking Test

\begin{tabular}{|l|l|l|l|}
\hline Item number in original test & Item Diff. & Disc. Index & Belonging factor \\
\hline Item 1 & .90 & .27 & recency \\
\hline Item 2 & .80 & .53 & recency \\
\hline Item 3 & .84 & .43 & recency \\
\hline Item 4 & .86 & .37 & random similarity \\
\hline Item 5 & .85 & .40 & random similarity \\
\hline Item 10 & .80 & .37 & base rate \\
\hline Item 11 & .30 & .37 & base rate \\
\hline Item 12 & .26 & .21 & base rate \\
\hline
\end{tabular}

As seen in Table 3, item discrimination indexes of remaining 8 items are at acceptable levels and the average discrimination index is .37. Moreover; item difficulty index is calculated as .70 and it means that this test has medium level item difficulty index. Also, KR-20 reliability coefficient is found as .71, thus it is concluded that the test is reliable. As a result of the item statistics, no item is left in the sample size dimension because of removing those items from the test. That's why, three-factor structure is tested for confirmatory factor analysis and the structure is presented in Figure 2 below. 


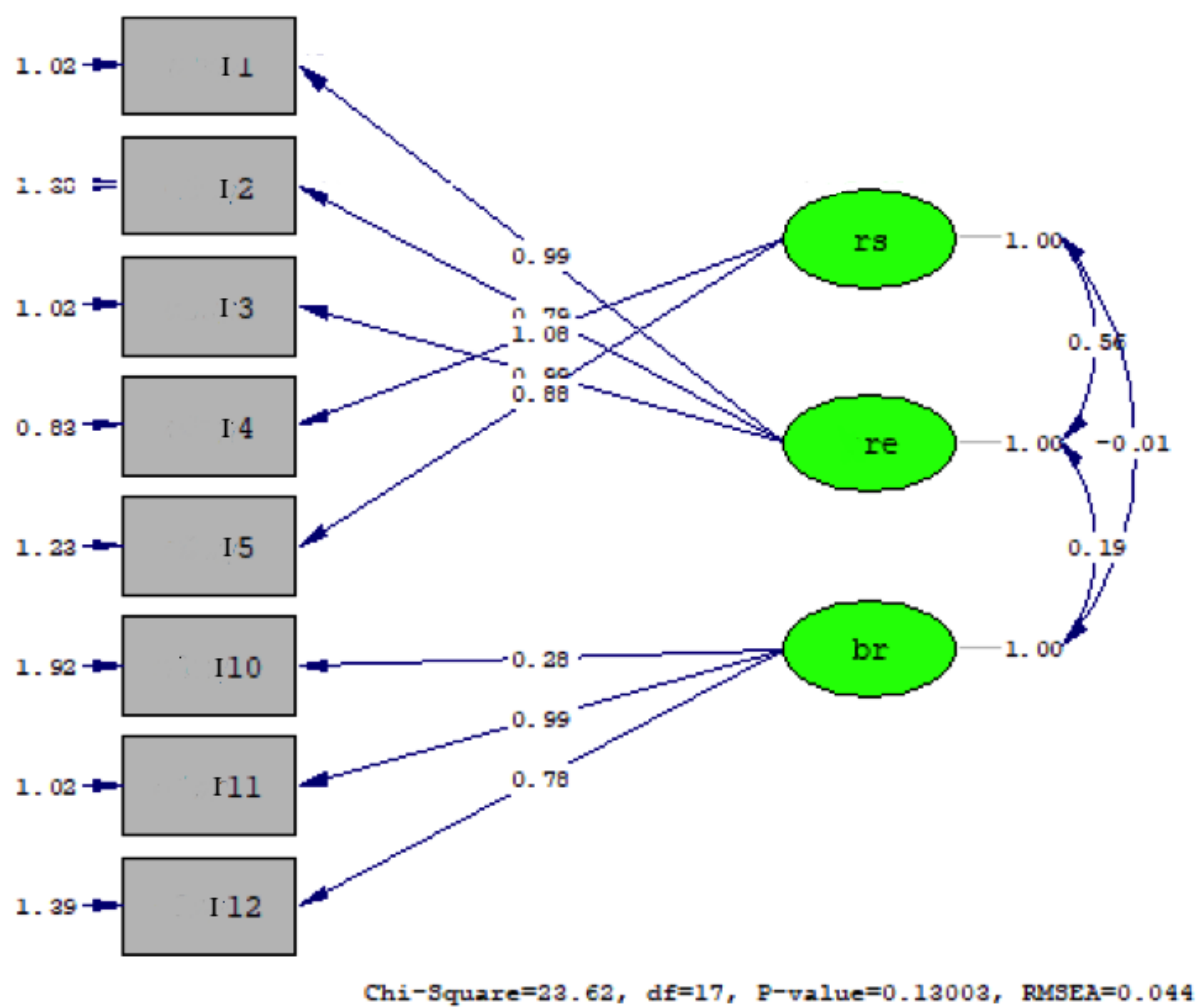

Figure 2. Confirmatory factor analysis of Probabilistic Thinking Test

As seen Figure 2, items 1-2-3 are in recency dimension; items 4-5 are in random-similarity dimension and items 10-11-12 are in base-rate frequency dimension, like original of the test. When the results of confirmatory analysis of Probabilistic Thinking Test are examined, it is seen that the all values are between goodness of fit indexes (Anderson and Gerbing 1984; Cole 1987). Those values are $\chi 2=$ $23.62, \mathrm{df}=17, \mathrm{p}=.00, \mathrm{RMSEA}=.04, \mathrm{CFI}=.97, \mathrm{NFI}=.90, \mathrm{NNFI}=.95$ and GFI $=.97$. As a result of the adaptation of probabilistic thinking test, it is used as a data collection tool in this study as an 8-item and 3-dimensional test.

\subsection{Data Analysis}

For the validity analyses of Probabilistic Thinking Test and Reflective Thinking Ability Scale Towards Problem Solving, confirmatory factor analysis is conducted through LISREL software. For reliability analysis of Probabilistic Thinking Test and Reflective Thinking Ability Scale, Cronbach alfa values for the whole scale and it's all dimensions are calculated through SPSS packet program. For reliability analysis of Probabilistic Thinking Test, KR-20 reliability coefficient analysis is calculated.

In order to determine which tests should be used for data analysis, the distribution characteristics of the scores obtained from the variables are examined. The related values are presented in Table 4 for each dimension of the instruments and for their total scores.

Table 4. Normality test results of the instruments

\begin{tabular}{|l|c|c|c|}
\hline Data collection tool/ dimension & Mean & Skewness & Kurtosis \\
\hline Probabilistic thinking test /recency & 2.68 & -2.39 & 4.82 \\
\hline Probabilistic thinking test /random similarity & 1.71 & -2.04 & 2.43 \\
\hline Probabilistic thinking test /base rate & 1.17 & .74 & .01 \\
\hline Probabilistic thinking test & 5.56 & -.56 & .55 \\
\hline
\end{tabular}




\begin{tabular}{|lrl|c|c|c|c|}
\hline $\begin{array}{l}\text { Reflective Thinking Skill Scale towards Problem Solving / } \\
\text { Questioning }\end{array}$ & 17.74 & -.04 & -.30 \\
\hline $\begin{array}{l}\text { Reflective Thinking Skill Scale towards Problem Solving / } \\
\text { Evaluating }\end{array}$ & 17.41 & .01 & -.67 \\
\hline $\begin{array}{l}\text { Reflective Thinking Skill Scale towards Problem Solving / } \\
\text { Reasoning }\end{array}$ & 14.64 & -.48 & -.06 \\
\hline Reflective Thinking Skill Scale towards Problem Solving & 49.79 & .01 & -.46 \\
\hline
\end{tabular}

According to Table 4, it is seen that the skewness and kurtosis values of the dimensions are examined, the probabilistic thinking test have different characteristics than the normal distribution in the recency and random similarity dimensions, since in a normal distribution, skewness and kurtosis values are between -2 and +2 values (George \& Mallery, 2003). Therefore, nonparametric tests are used for the analyses which include those two dimensions. Since the gender, that is the independent variable, has two sub-groups as male and female, Mann-Whitney $U$ test is applied for related dimensions. For the other dimensions and whole test scores, independent sample $t$ test is conducted, since those scores show normal distribution properties. Finally, the existence of the relationship between the two test scores are analyzed by Spearman correlation test (Büyüköztürk, 2013). Correlation analysis is carried out to determine the existence, direction and magnitude of the relationship between the variables which are continuous variables (Seçer, 2015). The correlation coefficients are interpreted according to criteria which are stated by Çokluk, Şekercioğlu, and Büyüköztürk (2016). They point out that when correlation value is .00, it means no correlation; when correlation value is between $0.01-0.29$, it means low correlation, when correlation value is between $0.30-0.69$, it means medium correlation and when correlation value is between $0.70-1$, it means high correlation.

\section{Findings}

The data of the study in the scope of research problems are presented through three headings.

\subsection{The Examination of Reflective Thinking Skill Scale Towards Problem Solving According to Gender}

First of all, independent samples t-test is conducted for total score obtained from Reflective Thinking Skill Scale Towards Problem Solving in order to determine whether there is a significant difference between male and female students. The results of it are presented in Table 5.

Table 5. Independent samples $t$-test results of Reflective Thinking Skill Scale towards Problem Solving of elementary school students according to their gender

\begin{tabular}{|c|c|c|c|c|c|c|}
\hline Data collection tool/dimension & Gender & $\mathbf{N}$ & $\mathbf{X}$ & SD & $\mathbf{t}$ & $\mathbf{p}$ \\
\hline \multirow{2}{*}{$\begin{array}{l}\text { Reflective Thinking Skill Scale towards Problem } \\
\text { Solving / Questioning }\end{array}$} & $\mathrm{M}$ & 98 & 17.53 & 3.36 & \multirow[t]{2}{*}{-.93} & \multirow[t]{2}{*}{.34} \\
\hline & $\mathrm{F}$ & 90 & 17.97 & 3.15 & & \\
\hline \multirow{2}{*}{$\begin{array}{l}\text { Reflective Thinking Skill Scale towards Problem } \\
\text { Solving / Evaluating }\end{array}$} & $\mathrm{M}$ & 98 & 17.21 & 3.71 & \multirow[t]{2}{*}{-.79} & \multirow[t]{2}{*}{.43} \\
\hline & $\mathrm{F}$ & 90 & 17.62 & 3.33 & & \\
\hline \multirow{2}{*}{$\begin{array}{l}\text { Reflective Thinking Skill Scale towards Problem } \\
\text { Solving / Reasoning }\end{array}$} & $\mathrm{M}$ & 98 & 14.33 & 3.46 & \multirow[t]{2}{*}{-1.31} & \multirow[t]{2}{*}{.19} \\
\hline & $\mathrm{F}$ & 90 & 14.96 & 3.08 & & \\
\hline \multirow{2}{*}{$\begin{array}{l}\text { Reflective Thinking Skill Scale towards Problem } \\
\text { Solving }\end{array}$} & $\mathrm{M}$ & 98 & 49.08 & 8.88 & \multirow[t]{2}{*}{-1.20} & \multirow[t]{2}{*}{.23} \\
\hline & $\mathrm{F}$ & 90 & 50.56 & 8.01 & & \\
\hline
\end{tabular}

The total score means obtained from Reflective Thinking Skill Scale Towards Problem Solving Scale and its dimensions of elementary school students according to their gender are given in Table 5. As seen in Table 5, the mean score of male students is 49.08 while the mean score of female students is 50.56 for the whole scale, where that difference between the groups is not statistically significant $(\mathrm{t}=-$ $1.20, \mathrm{p}=.23>.05)$.

When it comes to the dimensions, the mean score of male students in questioning dimension is 17.53; while the mean score of female students is 17.97. Like the result of whole scale, again this difference between the groups is not statistically significant $(\mathrm{t}=-.93, \mathrm{p}=.34>0.05)$. Similar results are obtained for 
both evaluating and reasoning dimensions. It is observed that the mean score of male students in evaluating dimension is 17.21 while the mean score of female students in the same dimension is 17.62 and no significant difference is seen between male and female students $(t=-.79, p=.43>.05)$. Finally, when the mean scores of students in reasoning dimension are examined, it is observed that the mean score of male students in this dimension is 14.33 while the mean score of female students is14.96. Again, there is no statistically significant difference between groups $(\mathrm{t}=-1.31 ; \mathrm{p}=.19>.05)$.

\subsection{The Examination of Probabilistic Thinking Test Score According to Gender}

Mann-Whitney $\mathrm{U}$ test is conducted for the recency and random similarity dimensions of probabilistic thinking test scores, since those variables do not have normal distribution properties. On the other hand, the base rate dimension and the whole test scores have normal distribution properties, so independent samples $t$ test is conducted for those two variables in order to determine whether there is a significant difference between male and female students. The results are presented in Table 6 and 7 .

Table 6. Mann-Whitney U test results of recency and random similarity dimensions of Probabilistic thinking test score according to gender

\begin{tabular}{|c|c|c|c|c|c|c|}
\hline Data collection tool/ dimension & Gender & $\mathbf{N}$ & $\mathbf{X}$ & $\begin{array}{l}\text { Mean of } \\
\text { Ranks }\end{array}$ & $\mathbf{U}$ & $\mathbf{p}$ \\
\hline \multirow{2}{*}{ Probabilistic thinking test/recency } & $\mathrm{M}$ & 98 & 2.67 & 9319.50 & \multirow{2}{*}{4351.50} & \multirow{2}{*}{.82} \\
\hline & $\mathrm{F}$ & 90 & 2.67 & 8446.50 & & \\
\hline \multirow{2}{*}{ Probabilistic thinking test/random similarity } & $\mathrm{M}$ & 98 & 1.71 & 9242.00 & \multirow{2}{*}{4391.00} & \multirow{2}{*}{.94} \\
\hline & $\mathrm{F}$ & 90 & 1.71 & 8524.00 & & \\
\hline
\end{tabular}

As seen in Table 6, the mean ranks of male students are 9319.50 in recency dimension and 9242.00 in random similarity dimension, while the mean ranks of female students are 8446.50 in recency dimension and 8524.00 in random similarity dimension. However; these differences between groups are not statistically significant $(\mathrm{U}$ for recency $=4351.00, \mathrm{p}=.82>.05$; $\mathrm{U}$ for random similarity $=4391.00$, $\mathrm{p}=.94>.05)$.

Table 7. Independent samples t test results of base rate dimension and whole test score of Probabilistic thinking test according to gender

\begin{tabular}{|l|l|l|l|l|l|l|}
\hline Data collection tool/dimension & Gender & N & X & SD & t & p \\
\hline \multirow{2}{*}{ Probabilistic thinking test /base rate } & $\mathrm{M}$ & 98 & 1.11 & .90 & -1.02 & \multirow{2}{*}{.30} \\
\cline { 2 - 5 } & $\mathrm{F}$ & 90 & 1.24 & .85 & & \\
\hline Probabilistic thinking test & $\mathrm{M}$ & 98 & 5.50 & 1.59 & -.62 & .53 \\
\cline { 2 - 5 } & $\mathrm{F}$ & 90 & 5.63 & 1.29 & & \\
\hline
\end{tabular}

As seen in Table 7 shows that, the mean of male students in base rate dimension is 1.11; where the mean of female is 1.24 and no difference is seen according to gender $(t=-1.302, p=.30>.05)$. Like as all dimensions, in terms of whole test scores again there is no significant difference according to gender $(\mathrm{t}=-.62 ; \mathrm{p}=.53>.05)$.

3.3. The Examination of Whether There is a Relationship Between Reflective Thinking Skill Scale towards Problem Solving Score and Their Probabilistic Thinking Test Score

Spearman rank correlation coefficients are calculated in order to determine whether there is a relationship between Reflective Thinking Skill Scale Towards Problem Solving of elementary school students and their probabilistic thinking test score. The results of them are presented in Table 8.

Table 8. Correlation between Reflective Thinking Skill Scale towards Problem Solving of elementary school students and their Probabilistic thinking test score

\begin{tabular}{|c|c|c|c|c|c|c|c|c|}
\hline \multirow{3}{*}{ Data collection tool/dimension } & \multicolumn{8}{|c|}{ Reflective Thinking Skill Scale Towards Problem Solving } \\
\hline & \multicolumn{2}{|c|}{ questioning } & \multicolumn{2}{|c|}{ evaluating } & \multicolumn{2}{|c|}{ reasoning } & \multicolumn{2}{|c|}{ total score } \\
\hline & $\mathrm{p}$ & $\mathrm{r}$ & $\mathrm{p}$ & $\mathrm{r}$ & $\mathrm{p}$ & $\mathrm{r}$ & $\mathrm{p}$ & $\mathrm{r}$ \\
\hline recency & .45 & -.06 & .68 & -.03 & .32 & -.07 & .39 & -.06 \\
\hline
\end{tabular}




\begin{tabular}{|l|l|l|l|l|l|l|l|l|l|}
\hline \multirow{3}{*}{$\begin{array}{l}\text { Probabilistic } \\
\text { thinking test }\end{array}$} & random similarity & .09 & .13 & .61 & .04 & .25 & .08 & .16 & .10 \\
\cline { 2 - 10 } & base rate & .28 & -.08 & .56 & -.04 & .70 & .03 & .77 & -.02 \\
\cline { 2 - 10 } & total score & .74 & -.03 & .56 & -.04 & .85 & -.01 & .77 & -.02 \\
\hline
\end{tabular}

$\mathrm{p}<.05$

As seen in Table 8, there are no a relation between the dimensions of Reflective Thinking Skill Scale towards Problem Solving of elementary school students and the dimensions of their Probabilistic thinking test score. In details, it is observed that the elementary school students' total score on Reflective Thinking Skill Scale Towards Problem Solving did not correlate with their total score on probabilistic thinking test score $(\mathrm{r}=-.02 ; \mathrm{p}=.77>.05)$. Moreover, the investigation of relation between dimensions of two data collection instruments is carried out separately for female and male students and the results are presented in Table 9.

Table 9. Examination of the relationship between Reflective Thinking Skill Scale Towards Problem Solving of elementary school students and their Probabilistic thinking test score in terms of their genders

\begin{tabular}{|c|c|c|c|c|c|c|c|c|c|c|}
\hline \multirow{3}{*}{\multicolumn{2}{|c|}{ Data collection tool/ dimension }} & \multirow[b]{3}{*}{ Gender } & \multicolumn{8}{|c|}{ Reflective Thinking Skill Scale Towards Problem Solving } \\
\hline & & & \multicolumn{2}{|c|}{ questioning } & \multicolumn{2}{|c|}{ evaluating } & \multicolumn{2}{|c|}{ reasoning } & \multicolumn{2}{|c|}{ whole scale } \\
\hline & & & $\mathrm{p}$ & $\mathrm{r}$ & $\mathrm{p}$ & $\mathrm{r}$ & $\mathrm{p}$ & $\mathrm{r}$ & $\mathrm{p}$ & $\mathrm{r}$ \\
\hline \multirow{8}{*}{$\begin{array}{l}\text { Probabilistic } \\
\text { thinking test }\end{array}$} & \multirow[b]{2}{*}{ recency } & $\mathrm{M}$ & .91 & -.01 & .93 & -.01 & .35 & .09 & .61 & -.05 \\
\hline & & $\mathrm{F}$ & -.11 & .32 & .55 & -.06 & .81 & -.03 & .47 & -.08 \\
\hline & \multirow[b]{2}{*}{ random similarity } & $\mathrm{M}$ & .02 & $.24 *$ & .74 & .03 & .56 & .06 & .19 & .13 \\
\hline & & $\mathrm{F}$ & .82 & .03 & .83 & .02 & .11 & .30 & .51 & .07 \\
\hline & \multirow[b]{2}{*}{ base rate } & $\mathrm{M}$ & -.19 & .07 & .82 & -.02 & .85 & .02 & .52 & -.07 \\
\hline & & $\mathrm{F}$ & .64 & .05 & .49 & -.07 & .84 & .02 & .92 & .01 \\
\hline & \multirow[b]{2}{*}{ whole test } & $\mathrm{M}$ & .64 & -.05 & .92 & -.01 & .52 & -.45 & .64 & -.05 \\
\hline & & $\mathrm{F}$ & .81 & .03 & .51 & -.07 & .54 & .07 & .88 & .02 \\
\hline
\end{tabular}

*correlation is significant at the .05 level

As see in Table 9, random similarity dimension of probabilistic thinking test shows correlation with questioning dimension of Reflective Thinking Skill Scale Towards Problem Solving significantly positive, but at low level $(\mathrm{p}=.02<.05 ; \mathrm{r}=.24)$. Except for this, no significant relationship is seen between the dimensions of scales according to gender.

\section{Result, Discussion and Suggestions}

Kızılkaya and Aşkar (2009) state that reflective thinking contributed learners to designing their learning strategies, producing and evaluating their alternative solutions to the problems, and revealing their implicit learning habits. Since gender is an important factor in many cognitive and affective behaviors, therefore it is thought that determination of whether reflective thinking and probabilistic thinking differ according to gender or not is important. As a result of the research, no significant differences are found between female and male students for all dimensions of Reflective Thinking Skill Scale Towards Problem Solving besides the whole test score. This finding complies with the study conducted by Köseoğlu, Demirci, Demir and Özyürek (2017). The researchers examine reflective thinking skill towards problem solving of seventh grade students according to gender by using the same scale and no significant difference is found. Moreover; the findings of another research which is conducted with pre-service teachers by Tuncer and Özeren (2012), is parallel with this research. They state that reflective thinking skill towards problem solving of pre-service teachers do not differ significantly according to gender in all dimensions and total score. However; the finding of this study differs with the result of the study conducted by Kızılkaya and Aşkar (2009). In related study it is stated that there is a significant difference in favor of female students. In addition to that, Kızilkaya and Aşkar (2009) state that the total mean score of female students is 51.68 and total mean score of male students is 48.99. In this study, it is observed that the total mean score of female students is 50.56 and total mean score of male students is 49.08 . According to those values, it may be said that total mean scores of both studies are very close to each other. It is thought that the disagreement derived from quality and quantity characteristics of the selected sample. For this reason, different studies may be conducted with different samples with different amount of member, in different 
cultures or with any other demographic characteristics in future. By this way, it can be seen that which kind of variables affect the Reflective Thinking Skills Towards Problem Solving and this will develop the related literature.

When the findings on probabilistic thinking test scores of the students are examined in this study, it is concluded that the again scores of the students do not differ significantly in total score and the dimensions of the scale according to the gender variable. This finding coincides with the result of Lamprianou and Lamprianou's research (2003). The researchers conclude that gender is not a predictor of the score obtained from the probability test. On the other hand, Afantiti-Lamprianou and Williams (2003) find that there are differences between male and female students and they mention that male students are affected more than females from the effects of representativeness heuristics. Similar finding is stated by Kreitler and Kreitler (1986). In the study, male students get higher score from probabilistic thinking test than females but they cannot find a clue about the cause for this gender differences. When it comes to this research, the fact that it is carried out with eighth grade students, may be considered as the reason why there is no difference according to gender. Because until eighth grade, students may have made sense of the concept of probability internally and may have reinforced to use it in their daily lives. Since students are formally faced with probability concept in eighth grade in our country, they have already developed their internal probability concept until that time. So that situation may be the reason of not observing difference according to gender, since that the daily life situations should not prompt more advantageous for a gender group. It is thought that it would be appropriate to construct the probability teaching according to the findings obtained by using different measurement tools in the studies to be carried out.

Finally, in previous studies conducted in the literature, significant relationships are observed between reflective thinking skills and mathematics success (Baş \& Kıv1lcım, 2012) as well as science and technology (Baş, 2013). However, there is no study of reflective thinking skills of elementary school students especially for probability learning area in mathematics curriculum. In this study, this gap is tried to be eliminated and no significant relation is found between the students' scores getting from all dimensions of the Reflective Thinking Skill Scale Towards Problem Solving and their probabilistic thinking test scores in all dimensions. However, in the analyzes performed separately for females and males, a significant but low-level relationship for female students between random similarity dimension of probabilistic thinking test and questioning dimension of Reflective Thinking Skill Scale Towards Problem Solving is seen. Although the relationship between other fields of mathematics, such as geometry, and reflective thinking ability (Baş \& Kıvılcım, 2003) is mentioned in the literature, such a relationship between the subject of probability and reflective thinking ability has not been exactly identified. This situation is thought to be due to the nature of the probability learning area. Since the subject of probability is perceived by students as more complex than other mathematics subjects, it is possible for students to develop prejudice on the subject that they perceive as more complex. So it can be said that they aren't be able to fully demonstrate their performance in the problem-solving process. For this reason, more detail information on problem solving processes which is obtained by conducting qualitative interviews with the students in the later studies, can be contributed to this subject. In addition, Hmelo-Silver (2004) and Lim (2011) find that problem-based learning environment improves reflective thinking of children. Therefore, it is thought that, a probability education based on problem solving may develop the reflective thinking skills of students with probabilistic thinking, because the ability of questioning provides more focus on the problemsolving process (Wopereis, Brand-Gruwe \& Vermetten, 2007), as stated in the literature.

\section{References}

Afantiti-Lamprianou, T., Williams, J. (2003). A scale for assessing probabilistic thinking and the representativeness tendency. Research in Mathematics Education, 5 (1), 173-196.

Anderson, J. C. \& Gerbing, D. W. (1984). The effect of sampling error on convergence, improper solutions, and goodness-of-fit indices for maximum likelihood confirmatory factor analysis. Psychometrika, 49(2), 155-173. 
Aydın, M. \& Çelik, T. (2013). The prospective teacher' opinions relating reflective thinking skills.

Pamukkale University Journal of Education, 34, 169-131. [Online: http://dergipark.gov.tr/download/article-file/114517.]

Amir, G. \& Williams, J. (1999). Cultural influences on children's probabilistic thinking. Journal of Mathematical Behavior, 18, 85-107.

Akgül, A. \& Çevik, O. (2003). İstatistiksel analiz teknikleri SPSS'te işletme uygulmaları [Statistical analysis techniques business applications in SPSS]. Ankara: Emek Ofset Ltd. Şti.

Baron, J. (1981). Reflective thinking as a goal in education. Intelligence, 5, 291-300.

Baş, G. (2013). Investigating the correlation between elementary students' reflective thinking skills towards problem solving and academic success in science and technology course with structural equation modeling. HAYEF: Journal of Education, 10 (2), 1- 12. [Online: https://search.proquest.com/openview/becf3d986ced05e286543fa3e78ee6ea/1?pq-

origsite $=$ gscholar \&cbl $=1796367]$

Baş, G. \& Beyhan, Ö. (2012). Effects of reflective thinking activities on students' academic achievement and attitudes towards English course. Amasya Education Journal, 1(2), 128-142. [Onine: http://dergi.amasya.edu.tr/article/view/1031000041/1031000021]

Baş, G., \& Kıvilcım, Z. S. (2012). The relationship between high school students' reflective thinking skills for problem solving and their academic success in mathematics and geometry. Paper presented at X. National Science And Mathematics Education Congress, Niğde University, Turkey, 27-30 June.

Bezzina, F. (2004). Pupils' understanding of probability \& statistics (14-15+): Difficulties and insights for instruction. Journal of Maltese Education Research, 2(1), 53-67.

Büyüköztürk, Ş. (2013). Sosyal bilimler için veri analizi el kitabı. [Handbook of data analysis for social sciences]. Pegem Yayıncilik: Ankara.

Chen, A. Y., Seng, S. H., Moo, S. N., Tan, S. C. \& Steven, T. (1992). Student teachers' reflection on classroom practice. Paper presented at Annual Conference of the Educational Research Association, Singapore, September 24-26. [Online: https://repository.nie.edu.sg/bitstream/10497/15329/1/ERAS1992-263_a.pdf.]

Cole, D. A. (1987). Utility of confirmatory factor analysis in test validation research. Journal of Consulting and Clinical Psychology, 55, 584-594.

Çokluk, Ö., Şekercioğlu, G. \& Büyüköztürk, Ş. (2010). Sosyal bilimler için çok değişkenli istatistik SPSS ve LISREL uygulamalarn [SPSS and LISREL applications of multivariate statistics for social sciences]. Ankara: Pegem Akademi Yayınc1lı.

Dewey, J. (1933). How we think: A restatement of the relation of reflective thinking to the educational process. Lexington, MA: Heath.

Ebel, R. L. (1972). Essentials of educational measurement. NJ: Prentice-Hall.

Erginel, S. Ş. (2006). Developing reflective teachers: A study on perception and improvement of reflection in pre-service teacher education. PhD dissertation, Middle East Technical University. [Online: https://tez.yok.gov.tr/UlusalTezMerkezi/tezSorguSonucYeni.jsp]

Ersözlü, Z. N. (2008). The effects of reflective thinking activities on the academic successes and attitudes of fifth grade primary social studies students. PhD dissertation, Firat University. [Online: https://tez.yok.gov.tr/UlusalTezMerkezi/tezSorguSonucYeni.jsp]

Fong, G. T., Krantz, D. H. \& Nisbett, R. E. (1986). The effects of statistical training on thinking about everyday problems. Cognitive Psychology, 18, 253-292.

Fraenkel, J. R., \& Wallen, N. E. (2009). How to design and evaluate research in education. NY: McGraw-Hill Companies. 
George, D., \& Mallery, P. (2003). SPSS for Windows step by step: A simple guide and reference. Boston, USA: Allyn \& Bacon.

Hmelo-Silver, C. E. (2004). Problem-based learning: What and how do students learn? Educational Psychology Review, 16(3), 235-266.

Kafoussi, S. (2004). Can kindergarten children be successfully involved in probabilistic tasks?. Statistics Education Research Journal, 3(1), 29-39.

Karasar, N. (2011). Bilimsel araştırma yöntemi: Kavramlar-ilkeler-teknikler [Scientific research method: Concepts-principles-techniques]. Ankara: Nobel Yayın Dağıtım.

Kizilkaya, G. (2009). The Effect Of Web-Based Learning Environments Supported With Reflective Thinking Activities To Problem Solving. PhD dissertation, Middle East Technical University. [Online: https://tez.yok.gov.tr/UlusalTezMerkezi/tezSorguSonucYeni.jsp.]

Kizılkaya, G., \& Aşkar, P. (2009). The development of a reflective thinking skill scale towards problem solving. Education and Science, 34(154), 82-92. [Onine: http://eb.ted.org.tr/index.php/EB/article/view/550/44 ].

Kosonen, P. O. (1992). Effects of teaching statistical laws on reasoning about problems. $\mathrm{PhD}$ dissertation, Simon Fraser University. [Online:https://scholar.google.com.tr/scholar?hl=tr\&as_sdt=0\%2C5\&q=Effects+of+teaching+statistic al+laws+on+reasoning+about+problems.+\&btnG=.]

Köksal, N. \& Demirel, Ö. (2008). The contributions of reflective thinking to pre-service teachers' teaching practice. Hacettepe University Journal of Education, 34, 189-203. [Onine: http://dergipark.gov.tr/download/article-file/87550 ]

Köseoğlu, E., Demirci, F. Demir, B. \& Özyürek, C. (2017). The Examination of 7th Grade Students' Reflective Thinking Skills towards Problem Solving: A Sample of Ordu City. International e-Journal of Educational Studies, 1(1), 60-68. [Onine: http://dergipark.gov.tr/download/article-file/390545]

Kreitler, S. \& Kreitler, H. (1986). Development of probability thinking in children 5 to 12 years old. Cognitive Development, 1(4), 365-390.

Lamprianou, I. \& Lamprianou, T. A. (2003). The probabilistic thinking of primary school pupils in Cyprus: The case of tree diagrams. International Group for the Psychology of Mathematics Education, $3,173-180$.

Lee, H. J. (2005). Understanding and assessing preservice teachers' reflective thinking. Teaching and Teacher Education, 21(6), 699-715.

Lim, L.-A. Y. L. (2011). A comparison of students' reflective thinking across different years in a problem-based learning environment. Instructional Science, 39(2), 171-188.

Polya, G. (1945). How to solve it: A new aspect of mathematical method. NJ: Princeton University Press.

Rodgers, C. (2002). Defining reflection: Another look at John Dewey and reflective thinking. Teachers College Record, 104(4), 842-866.

Schön, D. (1987). Educating the reflective practitioner: Toward a new design for teaching and learning in the professions. San Francisco: Jossey Bass Publications.

Seçer, İ. (2015). SPSS ve LISREL ile pratik veri analizi: Analiz ve raporlaştırma. [Practical data analysis with SPSS and LISREL: Analysis and reporting]. Ankara: An1 Yayınc1l1k.

Shaughnessy, J. M. (1992). Research in probability and statistics: reflections and directions. In Handbook of Research on Mathematics Teaching and Learning, D. A. Groups, (Ed.), New York: Macmillan, (pp. 465-494). 
Swings, S. \& Peterson, P. (1988). Elaborative and integrative thought processes in mathematics learning. Journal of Educational Psychology, 80(1), 54-66.

Şahin, Ç. (2009). An examination of journals of prospective science teachers according to their reflective thinking skills. Hacettepe University Journal of Education, 36, 225- 236. [Online: https://s3.amazonaws.com/academia.edu.documents/30838201/200936CIGDEM_SAHIN.pdf?AWSA ccessKeyId=AKIAIWOWYYGZ2Y53UL3A\&Expires $=1545198235 \&$ Signature $=$ YhUrEg21 YETzq4f DbpR\%2FQcOFgD4\%3D\&response-

contentdisposition=inline $\% 3 \mathrm{~B} \% 20$ filename $\% 3 \mathrm{DAn} \_$examination_of_journals_of_prospectiv.pdf]

Şanal, E.S. (2006). Developing reflective teachers: A study on perception and improvement of reflection in pre-service teacher education. Master Thesis, Middle East Technical University. [Onine: https://tez.yok.gov.tr/UlusalTezMerkezi/tezSorguSonucYeni.jsp ]

Tuncer, M. \& Ozeren, E. (2012). Prospective teacher's evaluations in terms of using reflective thinking skills to solve problems. Procedia-Social and Behavioral Sciences, 51, 666-671.

Watson, J. M. \& Moritz, J. B. (2002). School students' reasoning about conjunction and conditional events. International Journal of Mathematical Education in Science and Technology, 33(1), 59-84.

Way, J. (2003). The development of young children's notions of probability. Proceedings Of Cerme 3, Bellaria, [Online: http://www.dm.unipi.it/clusterpages/didattica/CERME3/proceedings/Groups/TG5/TG5_way_cerme3.pdf.]

Wopereis, I., Brand-Gruwe, S. \& Vermetten, Y. (2007). The effect of embedded instruction on solving information problems. Computers in Human Behavior, 24(3), 738-752.

Xie, Y., Ke, F. \& Sharma, P. (2008). The effect of peer feedback for blogging on college students' reflective learning processes. The Internet and Higher Education, 11(1), 18-25.

Yorulmaz, M. (2006). Evaluation of primary school teachers view and practices relating to the reflective thinking (An example of Diyarbakır city). $\mathrm{PhD}$ dissertation, Middle East Technical University. [Online: https://tez.yok.gov.tr/UlusalTezMerkezi/tezSorguSonucYeni.jsp.].

\section{Authors}

Feride OZYILDIRIM-GUMUS, Aksaray University, Aksaray (Turkey). E-mail: ferideozyildirimgumus@gmail.com

Gulnar OZYILDIRIM, Akdeniz University, Antalya (Turkey). E-mail: gulnarozyildirim@gmail.com

\section{Acknowledgement}

This work was supported by the Research Fund of Aksaray University, under Project Number 2018043. 